\title{
THE IMPACT OF PRECIPITATION ON WET DEPOSITION OF SULPHUR AND NITROGEN COMPOUNDS
}

\author{
WPŁYW OPADU ATMOSFERYCZNEGO NA MOKRĄ DEPOZYCJE \\ ZWIĄZKÓW SIARKI I AZOTU
}

\begin{abstract}
Atmospheric transport model FRAME has been used in this study to estimate the influence of precipitation on the patterns of wet deposition of oxidised sulphur, oxidised nitrogen and reduced nitrogen in Poland during the years 1981-2005. A constant wind and emission data and year-specific spatially interpolated precipitation data was used in the model. The results show that the correlation coefficient between mean annual precipitation totals and mean wet deposition is above 0.9 for all examined compounds. The spatial patterns of pollutant deposition are similar for all years, with the north-western part of Poland receiving the lowest and the southern, mountainous part, the highest pollutant load. The largest precipitation-induced changes in wet deposition budgets are observed for oxidised sulphur (53\% of the average amount between wet and dry year), and smaller for oxidised and reduced nitrogen (30\%). Inter-annual precipitation changes cause large variations in the amount of wet deposition of pollutants. This means that the emission abatements may not cause immediate environmental effects, $e g$ reductions in deposition of pollutants and, further ecosystems areas of exceeded critical loads.
\end{abstract}

Keywords: wet deposition, precipitation, FRAME, Poland

\section{Introduction}

Deposition of sulphur and nitrogen compounds is considered a major environmental issue - especially in Europe, where its effects were first observed. Deposition of acidifying and eutrophying compounds in Europe has significantly decreased over the last few decades $[1,2]$. Total deposition of oxidized sulphur and oxidized nitrogen dropped by $45 \%$ and $22 \%$, respectively, during the period 1980-2009. Deposition of reduced nitrogen, however, showed only $4 \%$ decrease [1]. These reductions are mainly a result of emission abatements. Due to technological development in industry and switching fuels from coal to oil and gas, emissions of $\mathrm{SO}_{2}$ and $\mathrm{NO}_{\mathrm{x}}$ have dropped significantly [3, 4]. In Poland, economic changes in the early 90 s also had a positive feedback on air quality $[5,6]$. Thanks to the Convention

\footnotetext{
${ }^{1}$ Department of Climatology and Atmosphere Protection, University of Wroclaw, ul. Kosiby 6/8, 51-621 Wrocław, Poland, phone +48 7134854 41, fax +48 713729498

${ }^{2}$ Centre for Ecology \& Hydrology, Edinburgh, Bush Estate, Penicuik, Midlothian, EH26 0QB, United Kingdom, phone +44 (0)13144543 43, fax +44(0)1314453943

*Corresponding author: kinga.walaszek@uni.wroc.pl
} 
on Long-Range Transboundary Air Pollution (CLRTAP) and the following protocols, which enforced further emission abatements and established long-term emission ceilings, the problem of acid deposition has reduced in importance in recent years, and the area with deposition exceeding critical loads for acidity has been significantly decreased [7]. On the other hand, the changes in emissions of reduced nitrogen $\left(\mathrm{NH}_{\mathrm{x}}\right)$ are small and further reductions are difficult to implement. Its main source is agriculture, both animal husbandry and crop cultivation, therefore abatements would carry significant economic costs.

The removal of pollutants from the atmosphere can occur in one of two ways: by wet deposition or dry deposition. Wet deposition is the process of washing out pollutants from the air by precipitation or cloud droplets, while dry deposition represents the collection of particles on receptor surfaces without the presence of hydrometeors [8]. Erisman et al [9] estimates that about $80 \%$ of pollutants deposited in Europe is a subject to wet deposition. In the temperate, transitional climate of Poland, with a considerable amount of precipitation, the process of wet deposition also encompasses the majority of total (wet and dry) national deposition budget. The EMEP-Unified model estimates that in year 2005, $303 \mathrm{Gg}$ of oxidized sulphur, $151 \mathrm{Gg}$ of oxidized nitrogen and $215 \mathrm{Gg}$ of reduced nitrogen was deposited in Poland. Over 65, 69 and $61 \%$ of these totals, respectively, were a due to wet removal. Similar numbers are provided by the FRAME model results. It estimates that $58 \%$ of oxidized sulphur and $61 \%$ of oxidized nitrogen was removed from the atmosphere by wet deposition. Studies carried out in Poland show that there is little year-to-year variability in dry deposition. Wet deposition, on the other hand, varies greatly, and the changes are consistent with precipitation variability [10]. Additionally, spatial and temporal patterns of wet deposition are not consistent with emissions [11, 12]. This indicates that rainfall is an important factor influencing wet deposition.

In this paper the Fine Resolution Atmospheric Multi-Pollutant Exchange model (FRAME) is applied to estimate spatial distribution of wet deposition of oxidized sulphur, oxidized nitrogen and reduced nitrogen in Poland for the years 1981-2005. The main aim of this study is to assess the role of precipitation in altering inter-annual variability of wet deposition of sulphur and nitrogen compounds. The model results are evaluated and compared with measurements for the reference year 2005. The differences between spatial distribution of wet deposition of sulphur and nitrogen in years with high and low precipitation totals are analyzed and wet deposition budgets are compared. The correlation between wet deposition budgets and annual precipitation sums is examined.

\section{Data and methods}

\section{Description of the FRAME model}

The Fine Resolution Atmospheric Multi-pollutant Exchange model is used for estimation of the spatial distribution of wet deposition of oxidised sulphur, oxidised nitrogen, and reduced nitrogen [13-15]. FRAME is a statistical Lagrangian trajectory model used to estimate air concentrations and deposition of atmospheric pollutants. The model domain covers the area of Poland with a domain size of $160 \times 160$ grids of $5 \mathrm{~km} \times 5 \mathrm{~km}$ resolution. Vertically the air column has a height of $2500 \mathrm{~m}$ and is divided into 33 layers with thickness varying from $1 \mathrm{~m}$ at the bottom of the domain to $100 \mathrm{~m}$ at the top of the mixing layer. Emission from point sources is treated with the plume rise model, and detailed information on stack parameters is provided [16]. The emission from area sources is 
injected into the first (in case of road traffic and agriculture) or the bottom three layers (in case of the remaining emission sectors). Pollutant concentrations at the edges of the domain are calculated using a larger scale model, FRAME Europe, with horizontal resolution of $50 \mathrm{~km} \times 50 \mathrm{~km}$ covering the entire Europe.

Horizontal advection of the air column across the domain occurs along a set of straight-line trajectories with angular resolution of $1^{\circ}$. The advection is dependent on wind speed and wind frequency roses, derived from radiosonde data measured at eight stations: Wroclaw, Legionowo, Leba (all three sites located in Poland), Greifswald, Lindenberg (both in Germany), Prague (Czech Republic), Poprad (Slovakia) and Kiev (Ukraine) [10]. Wind roses are based on the method proposed by Dore et al [17], with radiosonde data taken from above the friction layer $(750-700 \mathrm{hPa})$ and annual harmonic mean wind speed calculated for each wind direction. In this paper, wind roses for the year 2005 were used in all simulations, as this year was used as the reference year and to analyse only the role of precipitation on wet deposition of sulphur and nitrogen.

The chemistry module includes a set of gas-phase and aqueous phase reactions, including oxidation and photodissociation of oxidized sulphur and oxidized nitrogen, and transformation of reduced nitrogen into ammonium sulphate and ammonium nitrate. Dry deposition velocity is calculated individually for each of the five land use classes: forest, grassland, moorland, arable and urban. These categories are derived from Corine Land Cover database. In the case of wet deposition, a constant drizzle approach is implemented, assuming that precipitation is equally distributed in time. Gridded information on rainfall is derived from data from meteorological stations, in the form of spatially interpolated annual precipitation maps. In mountainous regions, the seeder-feeder mechanism is incorporated in the FRAME model. This phenomenon involves washing out cloud droplets from orographic cloud (the "feeder" cloud) by rain from upper level cloud. Due to higher pollutant concentration in feeder clouds, pollutant washout is significantly enhanced by this mechanism. It is estimated that seeder-feeder effect is responsible for a $50 \%$ increase in pollutant washout. This assumption is supported by measurements performed in Poland and other countries [18].

\section{Emission data}

Emission from point sources is provided from EPER and KASHUE databases. Data from the remaining sources was derived from the national emission inventory [19] using the methodology proposed by Kryza et al [20]. Total emissions of oxidized sulphur, oxidized nitrogen and reduced nitrogen in 2005 were 661,357 and $346 \mathrm{Gg}$, respectively. The main source of $\mathrm{SO}_{2}$ in Poland in year 2005 was the energy industry ( $71 \%$ of total $\mathrm{SO}_{2}$ emission in $2005)$, residential heating $(18 \%)$ and combustion processes in industry $(9 \%)$. In case of nitrogen oxides, road transport contributed by $42 \%$ to total annual emission in Poland, energy production industry by $34 \%$, and domestic heating - $9 \%$. The majority of ammonia emissions comes from agriculture $(97 \%)$. Nearly $75 \%$ of this is due to animal breeding and the remaining part is caused by fertilizer application.

\section{Precipitation data used in the model}

The role of precipitation on wet deposition is the main issue of this paper. Precipitation data used in the model is derived from annual totals measured at about 250 meteorological stations in Poland for the period 1981-2005. Point data was spatially interpolated using 
a modified ordinary kriging method, supported by the high resolution map of the long-term annual average precipitation. The long-term annual average precipitation (LTAP) map was developed from spatially interpolated data from ca. 2500 measurement sites for the period 1961-1980. For each year of the 1981-2005 period, point measurements of annual precipitation totals for a given year and each station were divided by LTAP data at station location. The calculated relative values of annual rainfall for a given year were then spatially interpolated using ordinary kriging [21], available through an R statistical package [22]. The interpolated data was then multiplied by long-term mean values of the LTAP map, using open-source GRASS GIS software [23]. This approach assured that the homogenous information on precipitation is used over the entire period, and the details of the spatial distribution of rainfall, available through LTAP (based on measurements from ca. 2500 sites) are preserved, despite the relatively small number of precipitation measurements.

Spatial information on precipitation was evaluated with the leave-one-out cross validation method. For a given year, each time one station was removed from the interpolation subset. For the location of the removed station, precipitation was interpolated with the remaining data, and the interpolation error was calculated as the difference between measured and estimated precipitation. The procedure was repeated for all stations in a given year. The interpolation error was summarized for each year using root mean square error statistic (RMSE).

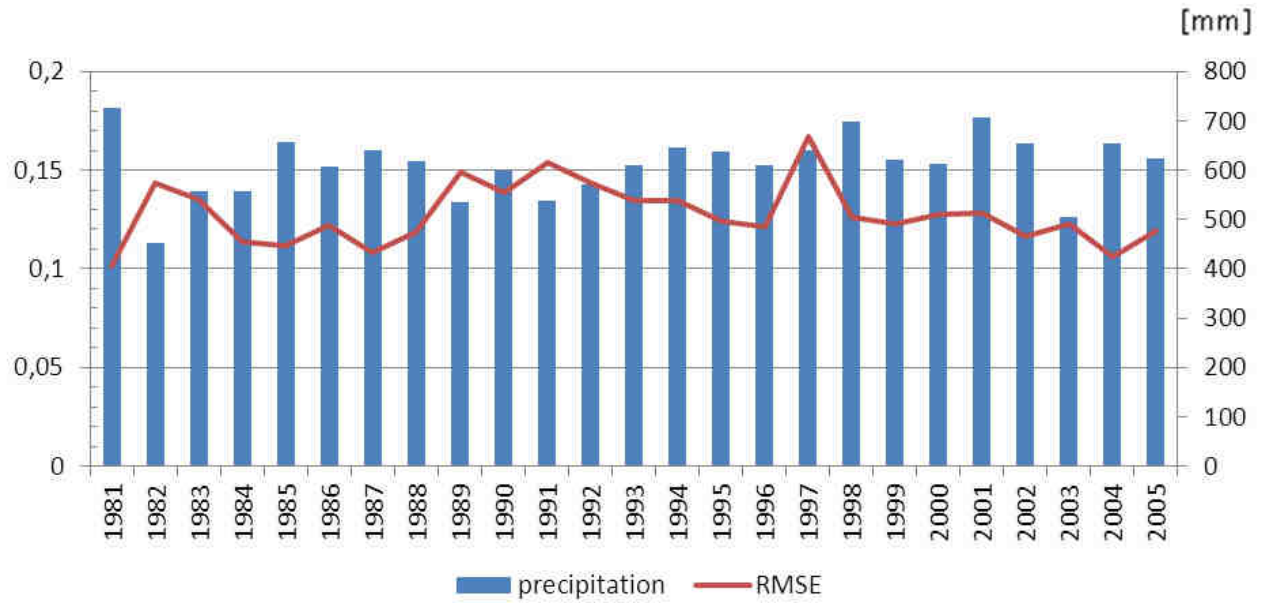

Fig. 1. Year specific RMSE relative to mean annual precipitation for the period 1981-2005

The RMSE values related to mean annual precipitation are shown in Figure 1. In most cases RMSE does not exceed 0.15 (15\%) of mean precipitation amount in a given year. The exception is year 1997, when it is close to 0.17, and 1991. The lowest RMSE is for 1981 (0.1). There is no statistically significant correlation between annual mean precipitation in Poland and interpolation error quantified by the RMSE statistic. For comparison, systematic error in measurement of precipitation by rain gauges is typically between $2-10 \%$ for rain and above $20 \%$ for snow [24]. 


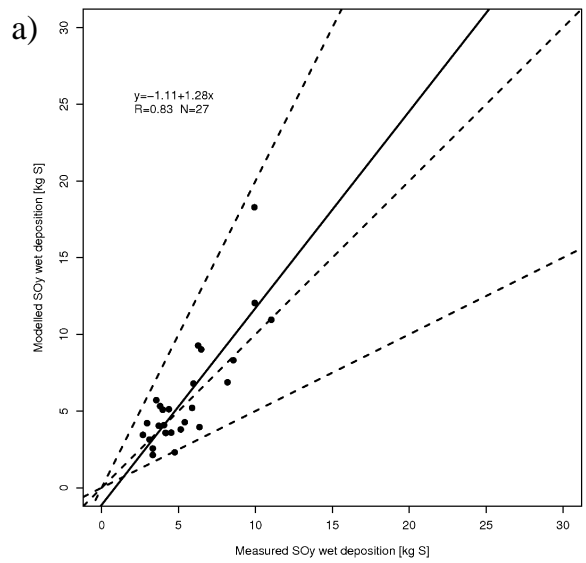

b)

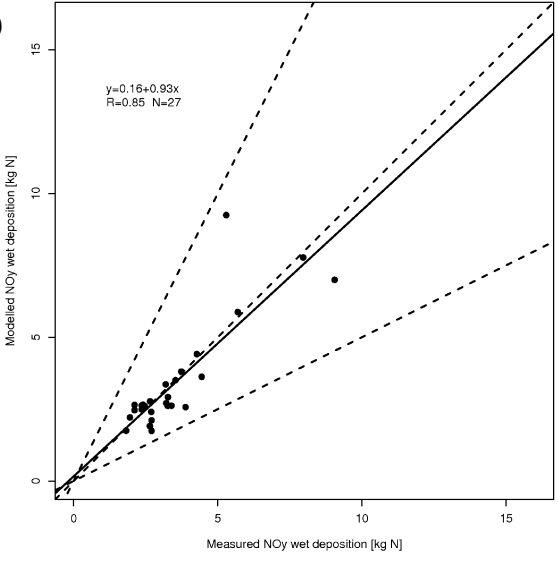

c)

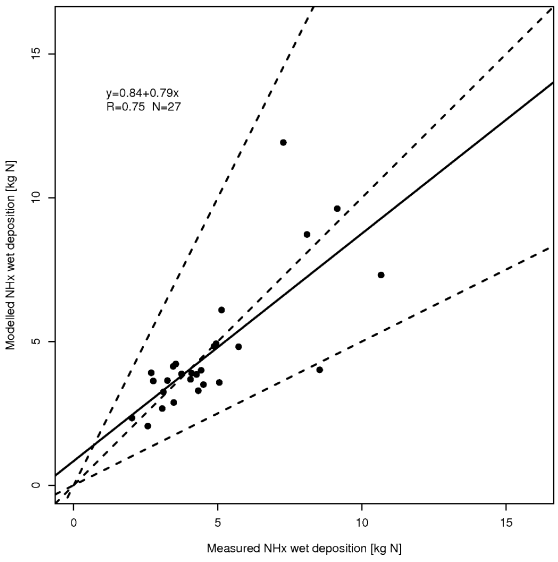

Fig. 2. Modelled vs. measured wet deposition of oxidised sulphur (a), oxidised nitrogen (b) and reduced nitrogen (c) in the reference year 2005 


\section{FRAME model evaluation}

For the reference year 2005, for which the actual meteorological and emission data was used, the modelled wet deposition was compared with measurements collected at 25 Polish stations operated by the Institute of Meteorology and Water Management, and two sites located in Germany and Czech Republic. All sites were equipped with wet-only collectors and meet EMEP and World Meteorological Organization recommendations on wet deposition sampling. The model error for each station is calculated as the difference between the modelled and observed wet deposition. The errors are summarized with the commonly used statistics: mean bias (MB) and mean absolute gross error (MAGE) [25] and presented on the scatterplots (Fig. 2). The Pearson correlation coefficient is also provided on the scatterplots, together with the linear regression equation between modelled and measured wet deposition.

The modelled wet deposition of sulphur and nitrogen compounds is in overall good agreement with the measurements, with the Pearson correlation coefficient above 0.85 for oxidized sulphur and nitrogen and 0.75 for reduced nitrogen. Large overestimations of the observed wet deposition values are calculated for Kasprowy Wierch (Tatra Mts) for all chemical species. This was previously linked with the seeder-feeder effect parameterization applied [20]. There is no general tendency of the model for over or underestimation of the observed wet deposition, with the MB statistic close to zero for all chemical species considered. The average errors, described by MAGE, are 1.4, 0.6 and $1.0 \mathrm{~kg} \mathrm{~N}$ or S ha ${ }^{-1}$ year ${ }^{-1}$ for wet deposition of $\mathrm{SO}_{\mathrm{x}}, \mathrm{NO}_{\mathrm{y}}$ and $\mathrm{NH}_{\mathrm{x}}$, respectively.

\section{Assessment of the role of annual precipitation changes on wet deposition budget in Poland}

In order to assess the role of precipitation on spatial distribution of sulphur and nitrogen wet deposition, constant emission, wind speed, and wind frequency information was used for all simulations performed for years 1981-2005. For a model run for a given year of the analysed period, year specific precipitation was used, which was the only factor that was being changed, and therefore responsible for changes in wet deposition. With this approach, it was possible to quantitatively assess the role of precipitation alone on wet deposition in Poland. With the long term precipitation data used in this study, it was also possible to cover the large range of natural year to year precipitation variability and, therefore, quantify the rainfall-induced (ie independent from human activity, eg emission abatements) variation in wet deposition in Poland.

The annual national wet deposition budget for Poland (NWDB; total mass of wet deposited pollutants in Poland) was calculated for sulphur and nitrogen compounds for all years separately. The range of precipitation-induced changes in NWDB was calculated for all chemical species considered. Correlation between the NWDB and the annual country average precipitation (derived from precipitation maps) was calculated, based on simulations for the entire period. This was performed to quantitatively describe the relation between the annual precipitation and NWDB.

From the set of interpolated precipitation maps for the period 1981-2005, years with the lowest, average and highest mean precipitation totals were selected for presentation and detailed analysis. Precipitation data from these years was then compared with wet deposition maps in search for common features. Spatial patterns of wet deposition for the 
selected reference (2005), dry and wet years are presented for sulphur and nitrogen compounds. The grid to grid correlation coefficient was calculated to quantify the changes in spatial pattern of $\mathrm{SO}_{\mathrm{x}}, \mathrm{NO}_{\mathrm{y}}$ and $\mathrm{NH}_{\mathrm{x}}$ deposition between the reference, dry and wet year in terms of annual precipitation in Poland.

\section{Results}

The results are organized as follows. First, the spatial patterns of annual rainfall in Poland are discussed for the reference year (2005) and compared with the selected dry (1982) and wet (2001) years. Following, the results of wet deposition modelling with the FRAME model for reference, dry and wet years are presented, and precipitation-induced changes in deposition are analysed spatially. Finally, the changes in national deposition budget for the period 1981-2006 are shown in terms of the year to year variation in annual precipitation in Poland.

\section{Spatial patterns of annual precipitation and wet deposition of sulphur and nitrogen}

The highest annual precipitation in the reference year 2005 was calculated for the mountainous areas in the south of Poland (Fig. 3). For the several grid squares in the Tatra Mts. and Sudety Mts., the maxima exceeded $1500 \mathrm{~mm}$. The hilly region of northern Poland was the area with the second highest average annual precipitation. The lowest annual precipitation is characteristic for central Poland, and for large areas does not exceed $500 \mathrm{~mm}$. The country average annual precipitation for the reference year 2005 was $602 \mathrm{~mm}$. For the dry year, average annual rainfall was $445 \mathrm{~mm}$, and $731 \mathrm{~mm}$ for the wet year. There is a strong grid to grid correlation between the spatial pattern of precipitation in the reference year 2005 and the dry year 1982 (0.89) and the wet year $2001(0.91)$.

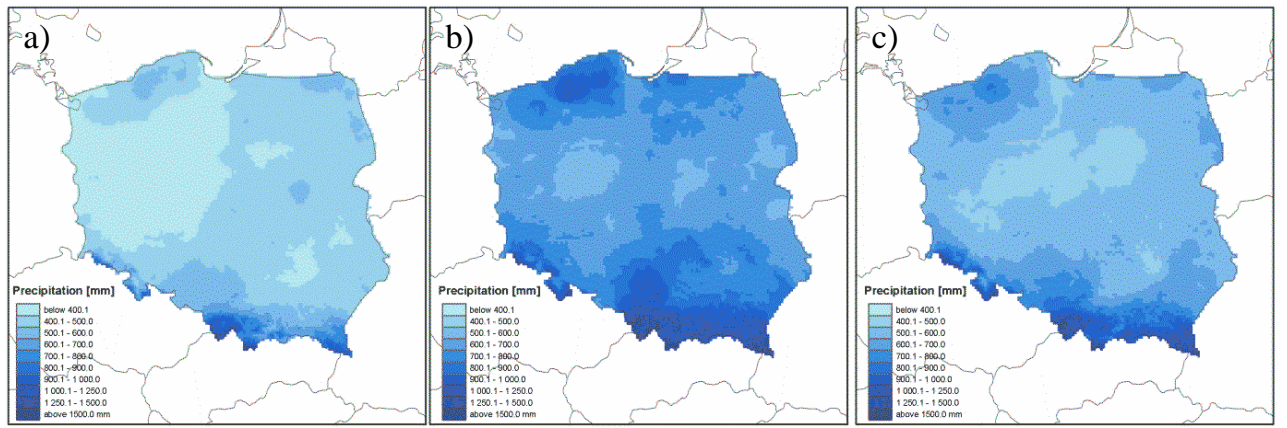

Fig. 3. Spatial distribution of annual precipitation in dry year $(1982$; a), wet year $(2001$; b), and reference year $(2005 ;$ c)

The spatial distribution of wet deposition of sulphur and nitrogen compounds in the reference year 2005 is presented in Figure 4. For oxidised sulphur, the lowest values are calculated in the northern area of the country. High values of wet deposition are in the south and in proximity of major emission point sources, with the maximum value of $19 \mathrm{~kg} \mathrm{~S} \mathrm{ha} \mathrm{yr}^{-1}$ in the Tatra Mts. Figure 4a also shows hot spots for sulphate wet deposition near major sulphur point source emissions which may be caused by washout of 
$\mathrm{H}_{2} \mathrm{SO}_{4}$. For oxidised nitrogen, the spatial pattern is similar to wet deposition of sulphur. The areas with the lowest deposition rates are north and northeast, while the south receives the highest load of atmospheric pollutants, with the maximum value of $10 \mathrm{~kg} \mathrm{~N} \mathrm{ha}^{-1} \mathrm{yr}^{-1}$ calculated in the Tatra Mts. In the case of reduced nitrogen, pollutant loads are more evenly distributed. The northern margins of Poland are below average and the mountains in the south have significantly higher values, with the extremes also in the highest part of Polish Carpathians. To a certain extent, wet deposition of ammonium shows spatial similarities with deposition of nitrate and sulphate due to the washout of fine ammonium nitrate and ammonium sulphate particles. However reduced nitrogen deposition can also locally have high values in lowland agricultural areas due to the solubility of ammonia gas. The average deposition loads are 5,3 and $4 \mathrm{~kg} \mathrm{~S} / \mathrm{N} \mathrm{ha}^{-1} \mathrm{yr}^{-1}$ of oxidised sulphur, oxidised nitrogen and reduced nitrogen, respectively.
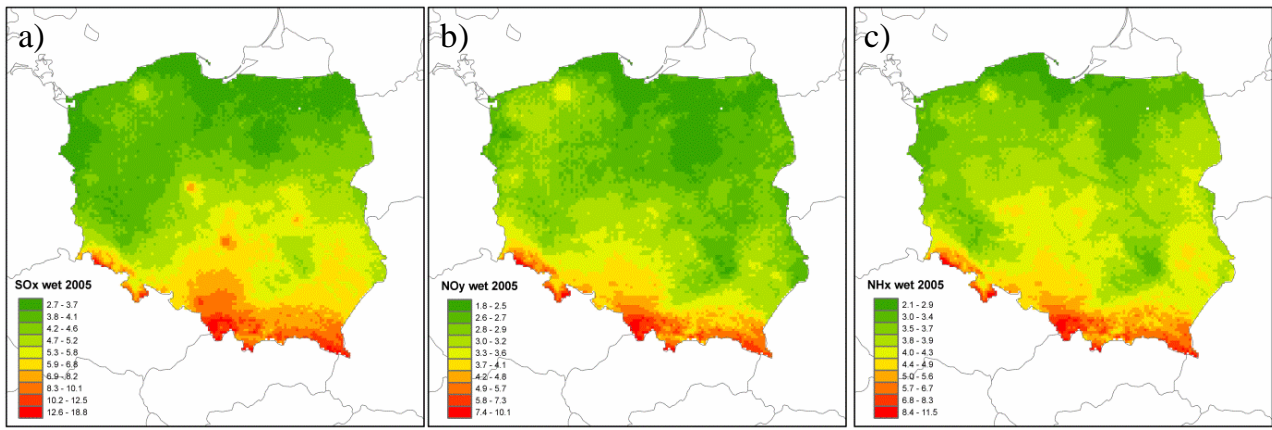

Fig. 4. Wet deposition of oxidized sulphur (a), oxidized nitrogen (b) and reduced nitrogen (c) in the reference year $2005\left[\mathrm{~kg} \cdot \mathrm{ha}^{-1}\right]$

In a dry year, wet deposition of all of the analysed chemical species have the highest values in the southernmost, mountainous part of Poland (Fig. 5). Wet deposition of reduced and oxidized nitrogen in the region exceeds $5 \mathrm{~kg} \mathrm{~N} \mathrm{ha} \mathrm{yr}^{-1}$ and $4 \mathrm{~kg} \mathrm{~N} \mathrm{ha}^{-1} \mathrm{yr}^{-1}$, respectively. Large sulphur deposition is also calculated for the emission source areas, the Upper Silesia region and small areas in central Poland, in the vicinity of large cities and large coal fired power plants. In hilly areas in the south, high precipitation totals and the seeder-feeder effect are responsible for the increased deposition of pollutants in both dry and wet years. Acidifying pollutants are easily dissolved in cloud water and can be transported both in clouds and as aerosol particles for long distances until they are removed from the atmosphere by precipitation.

The lowest wet deposition of all chemical species considered in the dry year 1982 were calculated for the north-western part of the country. This results from both relatively small precipitation amounts (not exceeding $400 \mathrm{~mm} \mathrm{yr}^{-1}$ ), combined with the absence of large emission sources, especially for oxidised sulphur and nitrogen, and the prevailing wind direction (west), which brings relatively unpolluted air from the Atlantic Ocean and Baltic Sea. Wet deposition in the north and northwest part of Poland is below $2.5 \mathrm{~kg} \mathrm{~S} \mathrm{ha}^{-1} \mathrm{yr}^{-1}$ of oxidized sulphur, $2.2 \mathrm{~kg} \mathrm{~N} \mathrm{ha}^{-1} \mathrm{yr}^{-1}$ of oxidized nitrogen and $2.6 \mathrm{~kg} \mathrm{~N} \mathrm{ha}^{-1} \mathrm{yr}^{-1}$ of reduced nitrogen, if the dry year is considered (Fig. 5). 
a)
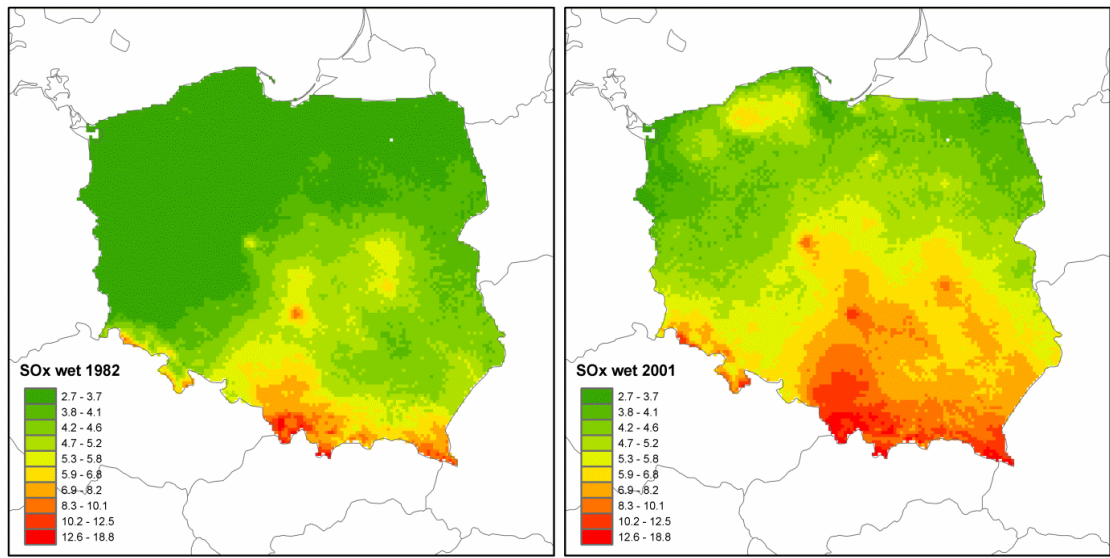

b)
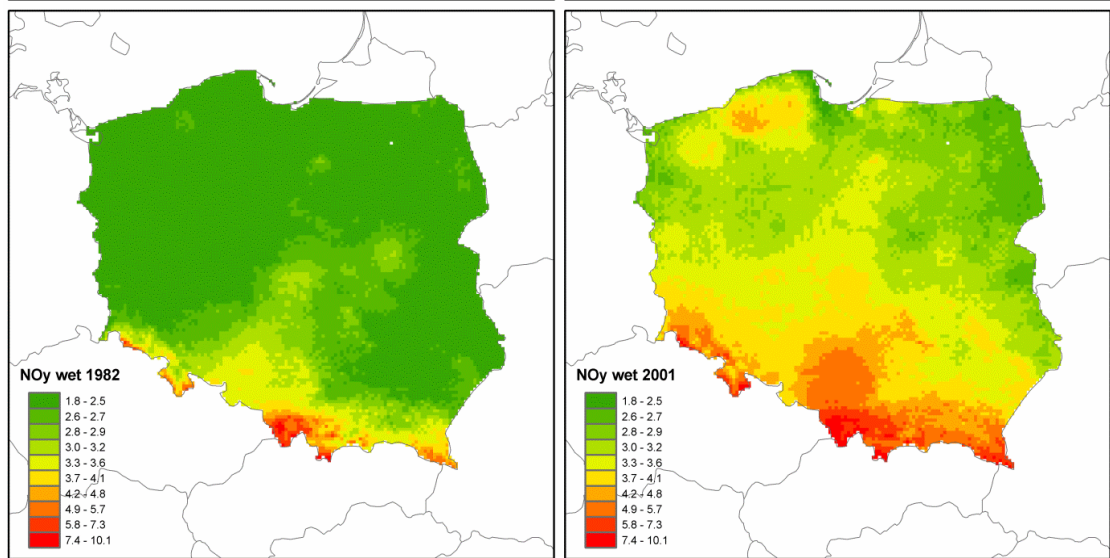

c)
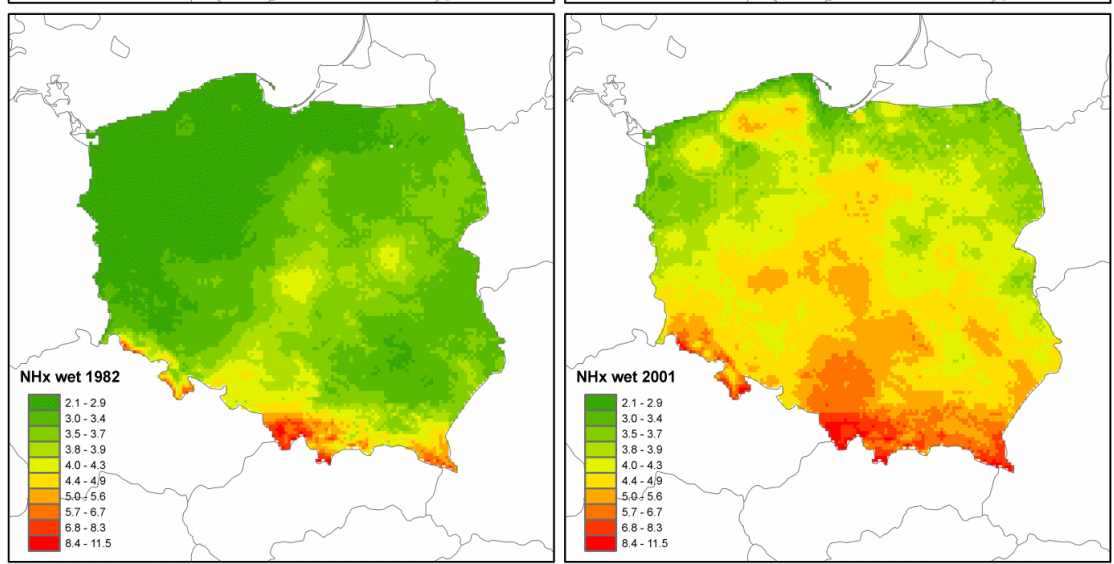

Fig. 5. Deposition of oxidised sulphur (a), oxidised nitrogen (b), and reduced nitrogen (c) in a dry year (left column) and wet year (right column) $\left[\mathrm{kg} \cdot \mathrm{ha}^{-1}\right]$ 
In the wet year (2001), the wet deposition is considerably higher than calculated for the dry and reference years. The wet deposition of oxidized sulphur exceeds $7 \mathrm{~kg} \mathrm{~S} \mathrm{ha}^{-1} \mathrm{yr}^{-1}$ over considerable area of Poland, including the centre, south and southeast (Fig. 5). Also the hilly regions in the north of Poland suffer from elevated deposition rates due to aboveaverage precipitation. With a constant amount of pollutants injected in the atmosphere and higher precipitation, the washout rate is more efficient and more pollutants are removed from the atmosphere, both by rainout and washout mechanisms.

Despite the differences in total mass of wet deposited sulphur and nitrogen, the spatial patterns of wet deposition are similar in the reference, dry and wet years (Figs. 4 and 5). Changes in spatial distribution are especially small for sulphur deposition, with the grid to grid correlation coefficient at 0.95 , even if dry and wet years are directly compared (Table 1). The largest changes in spatial distribution of wet deposition due to precipitation are for reduced nitrogen, however, the grid to grid correlation between the reference, dry and wet years are still above 0.88 and statistically significant. The less linear response of nitrogen deposition to changes in precipitation may be due to the sensitive chemical equilibrium reaction between nitric acid and ammonia gas to form ammonium nitrate aerosol.

Table 1 Grid to grid correlation coefficients between the wet deposition of sulphur and nitrogen compounds calculated for the reference (2005), dry (1982) and wet (2001) years

\begin{tabular}{|c|c|c|c|}
\hline & 2005 & 1982 & 2001 \\
\hline \multicolumn{4}{|c|}{$\mathrm{SO}_{\mathrm{x}}$ wet deposition } \\
\hline 2005 & 1.0 & 0.96 & 0.96 \\
\hline 1982 & & 1.0 & 0.95 \\
\hline 2001 & & & 1.0 \\
\hline \multicolumn{4}{|c|}{$\mathrm{NO}_{\mathrm{y}}$ wet deposition } \\
\hline 2005 & 1.0 & 0.92 & 0.94 \\
\hline 1982 & & 1.0 & 0.91 \\
\hline 2001 & & & 1.0 \\
\hline \multicolumn{4}{|c|}{$\mathrm{NH}_{\mathrm{x}}$ wet deposition } \\
\hline 2005 & 1.0 & 0.90 & 0.92 \\
\hline 1982 & & 1.0 & 0.88 \\
\hline 2001 & & & 1.0 \\
\hline
\end{tabular}

\section{Changes in national wet deposition budget}

For the reference year 2005, the total mass of wet deposited sulphur is $156.3 \mathrm{Gg} \mathrm{S}$. For the oxidized and reduced nitrogen, the respective values are 95.0 and $121.7 \mathrm{Gg} \mathrm{N}$. The average mass of wet deposited sulphur and nitrogen compounds, calculated with the FRAME model for the period 1981-2005 is $156.2 \mathrm{Gg} \mathrm{S}, 96.5 \mathrm{Gg} \mathrm{N}$ and $124.1 \mathrm{Gg} \mathrm{N}$ for oxidised sulphur, oxidised nitrogen and reduced nitrogen, respectively. The variability of deposition budgets is presented in Figure 6. The largest precipitation-induced changes in the 1981-2005 period are for wet deposition of sulphur, with the standard deviation at 16.7. For the nitrogen compounds, the respective standard deviations are 8.2 for $\mathrm{NH}_{\mathrm{x}}$ and 7.3 for wet $\mathrm{NO}_{\mathrm{y}}$. The range (max NWDB - min NWDB) is at 30\% of the 1981-2005 average deposition of nitrogen compounds, and is significantly higher for sulphur (53\%). The year-to-year deposition changes of NWDB are closely related to precipitation variability. The correlation coefficient between precipitation and deposition of each of the three species is above 0.9 , showing a very strong connection (Fig. 2). The changes in wet deposition in dry and wet 
years compared with the reference year are, however, smaller than changes in precipitation. Total rainfall in wet and dry years is $114 \%$ and $73 \%$ of the reference year, whereas deposition of all analysed species is about $115 \%$ for the wet year and $82 \%$ in the dry year. The difference between the change in precipitation and deposition in dry year could be due to higher concentrations of pollutants in the atmosphere in years with lower precipitation, as the decreased precipitation increases aerosol loading in the atmosphere.

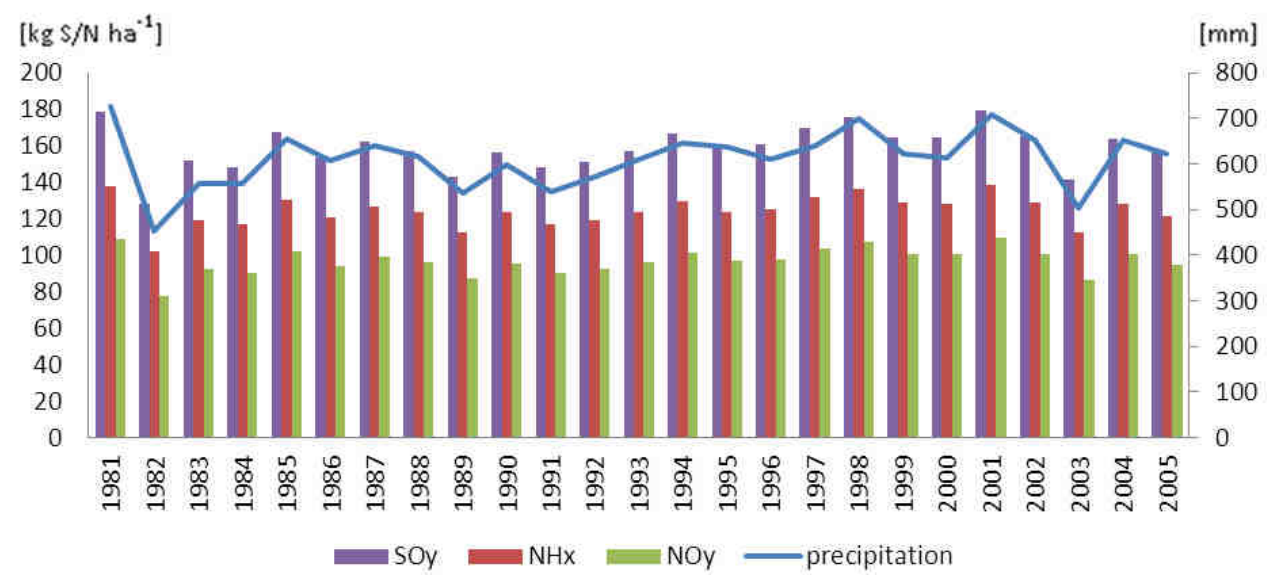

Fig. 6. Wet deposition budgets of oxidized sulphur, oxidized nitrogen and reduced nitrogen in Poland modelled by FRAME and mean annual precipitation totals

\section{Summary and conclusions}

The FRAME model has been applied in this study to assess the role of precipitation in wet deposition of oxidised sulphur, oxidised nitrogen and reduced nitrogen in Poland. This was done by performing 25 annual simulations for which constant emission and wind data were used, and the only factor that was changed was precipitation.

Both the spatial pattern and national deposition budget were found to be strongly correlated with the year to year changes in precipitation. The highest loads of acidifying and eutrophying pollutants were calculated for the regions with high precipitation sums. It was also found, that the general spatial pattern of wet deposition does not change significantly, even if the country average annual precipitation change. The regions of increased wet deposition of sulphur and nitrogen are permanently affected by elevated loads of sulphur and nitrogen in average, dry and wet years in terms of country averaged annual rainfall. The areas of above average wet deposition, eg mountains in the south of Poland, are often the regions with ecosystems of low resistance to acid and eutrophic deposition, eg coniferous forests, therefore this finding is of importance in terms of long term ecosystem protection in Poland [26].

The results presented in this paper show that even with constant emission, national wet deposition budget of sulphur and nitrogen compounds may vary greatly, depending on year to year changes in precipitation. This further means that emission abatements may not be immediately detected as measured decreases in pollutant deposition. As a result, despite the national or international emission abatements, the critical loads may still be exceeded in 
some areas, which needs to be constantly monitored. This is of special importance concerning two issues. First, slower trends in emission abatements than in eg early 1990s, both in Poland and in entire Europe, means that the natural changes in meteorological conditions may be the main reasons for inter-annual variation in deposition of acidifying and eutrophying pollutants. Second, the dynamics of year to year changes in meteorological condition is expected to increase, due to changes in global climate. These results reinforce the need for long term monitoring programmes to detect environmental change caused by input of pollutants to natural ecosystems by precipitation.

\section{References}

[1] Vestreng V, Myhre G, Fagerli H, Reis S, Tarrason L. Atmos Chem Phys. 2007;7:3663-3681. DOI: 10.5194/acp-7-3663-2007.

[2] Mylona S. Tellus B. 1996;48:662-689. DOI: 10.1034/j.1600-0889.1996.t01-2-00005.x.

[3] Fagerli H, Aas W. Environ Pollut. 2008;154:448-461. DOI: 10.1016/j.envpol.2008.01.024.

[4] Giannitrapani M, Bowman A, Scott M, Smith R. Atmos Environ. 2006;40:2524-2532. DOI: 10.1016/j.atmosenv.2005.12.052.

[5] Mill W. Environ Sci Pol. 2006;9:563-567. DOI: 10.1016/j.envsci.2006.05.002

[6] Szyda J, Wierzbicki H, Stokłosa A. Statistical modelling of changes in concentrations of atmospheric $\mathrm{NO}_{2}$ and $\mathrm{SO}_{2}$. Pol. J Environ Stud. 2009;18:1123-1129.

[7] Mill W, Schlama A. Modeling critical loads of airborne acidity and eutrophication of Polish forest ecosystems - the SONOX model. Arch Environ Prot. 2010;36:117-126.

[8] Park SU. Journal of Applied Meteorology. 1998;37:486-496. DOI: 10.1175/15200450(1998)037<0486:EODDON>2.0.CO;2

[9] Erisman JW, Vermeulen A, Hensen A, Flechard C, Dämmgen U, Fowler D, et al. Environ Pollut. 2005;133:403-413. DOI: 10.1016/j.envpol.2004.07.004.

[10] Kryza M, Dore AJ, Błaś M, Sobik M. J Environ Manag. 2011;92:1225-1236. DOI: 10.1016/j.jenvman.2010.12.008.

[11] Fowler D, Smith R, Muller J, Cape JN, Sutton M, Erisman JW, et al. Water Air Soil Pollut.: Focus. 2007;7:41-47. DOI: 10.1007/s11267-006-9102-x.

[12] Matejko M, Dore AJ, Hall J, Dore CJ, Błaś M, Kryza M, et al. Environ Sci Policy. 2009;12:882-896. DOI: $10.1016 /$ j.envsci.2009.08.005.

[13] Singles R, Sutton MA, Weston KJ. Atmos Environ. 1998;32:393-399. DOI: 10.1016/S13522310(97)83467-X.

[14] Fournier N, Dore AJ, Vieno M, Weston KJ, Dragosits U, Sutton MA. Atmos Environ. 2004;38:683-694. DOI: 10.1016/j.atmosenv.2003.10.028.

[15] Dore AJ, Vieno M, Tang YS, Dragosits U, Dosio A, Weston KJ, et al. Atmos Environ. 2007;41:2355-2367. DOI: $10.1016 /$ j.atmosenv.2006.11.013.

[16] Vieno M, Dore AJ, Bealey WJ, Stevenson DS, Sutton MA. Sci Total Environ. 2010;408:985-995. DOI: 10.1016/j.scitotenv.2009.10.048.

[17] Dore AJ, Vieno M, Fournier N, Weston KJ, Sutton MA. Q J Roy Meteorol Soc. 2006;132:2769-2784. DOI: 10.1256/qj.05.198.

[18] Dore AJ, Sobik M, Migała K. Atmos Environ. 1999;33:3301-3312. DOI: 10.1016/S1352-2310(98)00294-5.

[19] Dębski B, Olendrzyński K, Cieślińska J, Kargulewicz I, Skośkiewicz I, Olecka A, et al. Inwentaryzacja emisji do powietrza $\mathrm{SO}_{2}, \mathrm{NO}_{2}, \mathrm{CO}, \mathrm{NH}_{3}$, pyłów, metali ciężkich, NMZO, TZO w Polsce za rok 2005 (in Polish). Warsaw: Institute of Environ Protect; 2009.

[20] Kryza M, Werner M, Błaś, M, Dore AJ, Sobik M. J. Air Waste Manag. Assoc. 2010;60:856-866. DOI: 10.3155/1047-3289.60.7.856.

[21] Szymanowski M, Kryza M. Clim Res. 2009;38:171-187. DOI: 10.3354/cr00780.

[22] R Development Core Team. R: A Language and Environment for Statistical Computing. Vienna: R Foundation for Statistical Computing, 2009.

[23] GRASS Development Team. Geographic Resources Analysis Support System (GRASS) Software. Open Source Geospatial Foundation, 2009. http://grass.osgeo.org.

[24] Sevruk B, Klemm S. Instruments and Observing Methods. Report no. 39. Catalogue of national standard precipitation gauges. World Meteorological Organization, 1989. 
[25] Yu S, Eder B, Dennis R, Chu S-H, Schwartz SE. Atmos Sci Let. 2006;7:26-34. DOI: 10.1002/asl.125.

[26] Hrkal Z, Fottová D, Rosendorf P. The relationship between quality of ground waters and forest cover in regions affected by high levels of acid atmospheric deposition - a case study of the Krušné Hory Mts., Czech Republic. Pol J Environ Stud. 2009;18:995-1004.

\title{
WPŁYW OPADU ATMOSFERYCZNEGO NA MOKRĄ DEPOZYCJE ZWIĄZKÓW SIARKI I AZOTU
}

\author{
${ }^{1}$ Zakład Klimatologii i Ochrony Atmosfery, Uniwersytet Wrocławski \\ ${ }^{2}$ Centrum Ekologii i Hydrologii w Edynburgu
}

\begin{abstract}
Abstrakt: Model transportu atmosferycznego FRAME został wykorzystany w niniejszej pracy do określenia wpływu opadów atmosferycznych na przestrzenną i czasową zmienność depozycji tlenków siarki, tlenków azotu oraz azotu zredukowanego na obszarze Polski w latach 1981-2005. W modelu zastosowano stałe warunki anemologiczne i emisję oraz mapy rocznych sum opadów uzyskane drogą interpolacji przestrzennej. Wyniki pokazują, że współczynnik korelacji między średnimi rocznymi sumami opadu a średnią mokrej depozycji przekracza 0,9 dla wszystkich analizowanych związków. Schemat przestrzenny depozycji kształtuje się podobnie dla całego okresu, z najniższymi ładunkami zanieczyszczeń w północno-zachodniej części Polski i najwyższymi w górzystej części południowej. Największe zmiany w budżecie depozycji spowodowane zmiennością opadów zachodzą dla tlenków siarki (53\% wartości średniej między rokiem suchym i wilgotnym), natomiast słabiej zaznacza się zmienność zarówno dla azotu utlenionego, jak i zredukowanego (30\%). Ze względu na to, że zmienność warunków pluwialnych powoduje znaczne wahania mokrej depozycji zanieczyszczeń, ograniczanie emisji może nie spowodować natychmiastowej poprawy dla środowiska, tzn. redukcji depozycji zanieczyszczeń i ograniczenia obszarów o przekroczonych ładunkach krytycznych.
\end{abstract}

Słowa kluczowe: mokra depozycja, opad atmosferyczny, FRAME, Polska 